\title{
Students' Perceptions of Mobile Technology in Higher Education: Preparation to Design Mobile Learning Models
}

\author{
Leni Pebriantika ${ }^{1,2, *}$, Maria Paristiowati ${ }^{3}$, Hartati Mochtar ${ }^{3}$ \\ ${ }^{1}$ Department of Educational Technology, Universitas Negeri Jakarta, Indonesia \\ ${ }^{2}$ Universitas Baturaja, Indonesia \\ ${ }^{3}$ Universitas Negeri Jakarta, Indonesia
}

Received July 9, 2019; Revised September 9, 2019; Accepted September 16, 2019

Copyright@2019 by authors, all rights reserved. Authors agree that this article remains permanently open access under the terms of the Creative Commons Attribution License 4.0 International License

\begin{abstract}
Education in the industrial revolution era 4.0 shows a change in the way of learning, thinking patterns and ideas of acting in high school students. One part that is inseparable from that is the use of mobile technology. This study aims to describe students' perceptions of the use of mobile technology as a tool for developing the right learning media in lecture activities at universities. This type of research is descriptive with a survey method of 100 students. The technique of collecting data uses a questionnaire. The findings show that students are very familiar with mobile technology, but the usage is still not directed according to the competencies to achieve in certain subjects. The results of this study also revealed that students have a positive perception of mobile technology. This report can be taken as a preparation for the design of a mobile learning model in higher education.
\end{abstract}

Keywords Students' Perceptions, Mobile Technology, Mobile Learning, Higher Education

\section{Introduction}

In the current era of globalization, the development of information and communication technology is increasing. They take effect in the world of education, especially in learning activities in higher education. Learning has undergone many changes along with the progress of the times. The concept of knowledge that was once monotonous and homogeneous has now changed and has many variations of the ideas of learning that can be applied. The change in the concept of teaching and learning is primarily to increase success in achieving learning goals. The purpose of learning is designed to be active and fast in attaining goals that can improve the quality of learning and education.

The quality of learning is also supported by student activities. To get information that supports learning activities, it is inseparable from the role of mobile technology and the emergence of mobile technology. Mobile technology makes communication run fast in its application to learning, offers benefits to facilitate and accelerate the process of delivering information and interchanges between students, lecturers, and other implementers of learning, and provides a positive impact that can accelerate the accuracy of achieving learning and education goals. There are many examples of learning to use mobile technology, for example, using personal digital devices of assistants and cellphones which are the most commonly used technologies in mobile learning (Naismith, Sharples, Vavoula, \& Lonsdale, 2004)

If they are associated with student trends in their daily life mobile technology. Sometimes the mobile technology cannot be used maximally for learning but is only used as a communication and entertainment suggestion. In line with that, this study wants to look at students' perceptions of mobile technology as a preparation for the design and development of mobile learning to support learning. All types of knowledge that occur in learning and space environments take into account technological mobility, student mobility and learning mobility (Your et al. 2014).

The development of mobile learning itself has been quite long. But not all universities, especially in Indonesia, have implemented it. The reason for not implementing mobile learning is positively very diverse. Research shows that impact mobile learning to apply in several countries such as Thailand, Malaysia (Chong, Chong, Ooi, \& Lin, 2011), Pakistan (Abu-Al-Aish \& Love, 2013), India, Nigeria, Taiwan (Hwang \& Chang, 2011) and other countries. In 
Indonesia, the application of mobile learning has been very rapid (Hanif, Asrowi, \& Sunardi, 2018). But to design mobile learning models that can later be useful for learning, of course, it must begin with understanding students' perceptions of mobile technology that is often used by students. The Higher Education Sector needs to be informed about the actual use of mobile devices, and potential future trends in mobile learning. (Marinakou \& Giousmpasoglou, 2015)

\section{Literature Review}

\subsection{Student Perceptions}

Students' Perception is a process of using the knowledge that has been possessed to obtain and interpret stimuli (stimuli ) which are accepted by the system in the human senses. Perception concerns the relationship between humans and the environment using the knowledge they have. Students' perception is a complex interaction that involves at least three main components, namely selection, preparation, and interpretation. (Rachmadhani, 2016)

\subsection{Mobile Technology}

Mobile technology is a 21st-century technology that experiences rapid development. The development of mobile technology is also accompanied by the development of the internet, one of which is the development of social networking sites. Most social site services provide facilities for users to interact with other users. In addition to communication between users, information can be obtained easily from the many available resources. The form of the application of mobile technology is the growing development of m-commerce, $\mathrm{m}$-money, m-library, and m-learning. The event was carried out to reach increasingly broad users. The results of research conducted show that mobile technology also has a positive impact on learning. (Kim-soon et al., 2015) The mobile technology

History of development began around 1980 with the birth of Generation One (1G) introduced as one-way communication. Then in 1991 it developed into the second Generation (2G) adding the capabilities of Short Message Services (SMS) and Multimedia Message Services (MMS), which allow picture messages to be sent and received via mobile devices. In 1998 a third-generation (3G) appeared and is introduced to offer faster data transmission speeds to support video calls and internet access. The fourth generation (4G) was released in 2008 to encourage more demanding services such as gaming services, HD cellular $\mathrm{TV}$, video conferencing, and so on. Soon there will be a Generation 5 (5G) that has planned for the future. In Generation 5 (5G) data will be sent via radio waves.

\subsection{Mobile Learning}

Mobile Learning (m-learning) is part of electronic learning (e-Learning)so that, by itself, it is also part of distance learning (d-Learning). The constructivist learning environment imposes a new role for lecturers. Lecturers are facilitators for students who will motivate students to achieve and hone skills, direct how students learn concepts both inside and outside the classroom. (Hamdani, 2013). In modern life, there are emerging devices that can support mobile learning including laptops, tablet PCs, PDAs, and smartphones. (Göksu \& Atici, 2013). Smartphone is a combination of voice, video, internet access and so on (Corbeil \& Valdes-corbeil, 2007) From the research data conducted by smartphone, it is the most widely used device in mobile learning. (Ken Nee Chee, Noraffandy Yahaya, Nor Hasniza Ibrahim, \& Mohamed Noor Hasan, 2017). Cellular learning technology has several general aspects such as portability, small size, interactivity, and everywhere. (Sönmez, Göçmez, Uygun, \& Ataizi, 2018)

Here are some real conditions related to the development of cellular telephones which are the operational background of the emergence of mobile learning, namely: (1). The development of mobile learning devices are high-speed; (2) More than a PC; (3) More easy to operate than a PC (4) Mobile learning devices can use as learnings' media. Thought in mobile learning is based on the main reasons, namely: (1) Can be used anytime anywhere (on the network / outside the network); (2) Wide coverage can use commercial cellular networks; (3) Integrity with other systems.

From the explanation above, Mobile Learning is unique learning because students can access learning materials, directions and applications related to education, whenever and wherever. It will increase attention to learning material, make learning pervasive, and can encourage learners' motivation to lifelong learning. Also, compared to conventional knowledge, Mobile Learning can provide opportunities for students to repeat learning materials according to their desires and level of understanding.

There are three functions of mobile learning in classroom learning activities, namely as a supplement, complement, and substitution.

a. Supplements

Mobile Learning functions as a supplement, namely students have the freedom to choose, whether to use mobile learning material or not. In this case, there is no requirement for students to access learning material.

\section{b. Complement}

Mobile learning functions as a compliment, namely the material is programmed to complement the learning material that students receive in the classroom. Here means free learning material is processed to become material reinforcement or remedial for students in participating in learning activities. 
c. Substitution

Several universities in developed countries provide several alternative models of learning activities for their students. The goal is to be able to flexibly manage the lecture activities according to the time and activities of students.

\section{Methodology / Materials}

This study aims to describe students' perceptions of the use of mobile technology. It prepared for developing a mobile learning model. The type of research conducted is quantitative descriptive with survey methods. The sample consisted of 100 students at Baturaja University consisting of 30 Faculty of Education students, 35 Economics Faculty students, and 30 Faculty of Social and Political Sciences students.

The distribution of questionnaires is done online which is distributed randomly to respondents. Data were analyzed quantitatively using percentages. The survey was designed to explore some information including the ownership of mobile technology, the time used in using mobile technology, applications that are used, and students' perceptions about the application of mobile learning models later.

\section{Results and Findings}

This section will present the results of the study. The results of this study were obtained from questionnaires distributed online to 100 students in 3 different faculties at Baturaja University. The survey consists of 5 parts, namely (1) Types of mobile technology that used; (2) Internet network access used; (3) The time used in using mobile technology; (4) Types of mobile applications that used; (5) Students' perceptions of mobile learning.

\subsection{Types of Mobile Technology Devices Used}

In this section we will explain the types of mobile technologies that are often used by students in supporting their activities. As shown in the following figure:

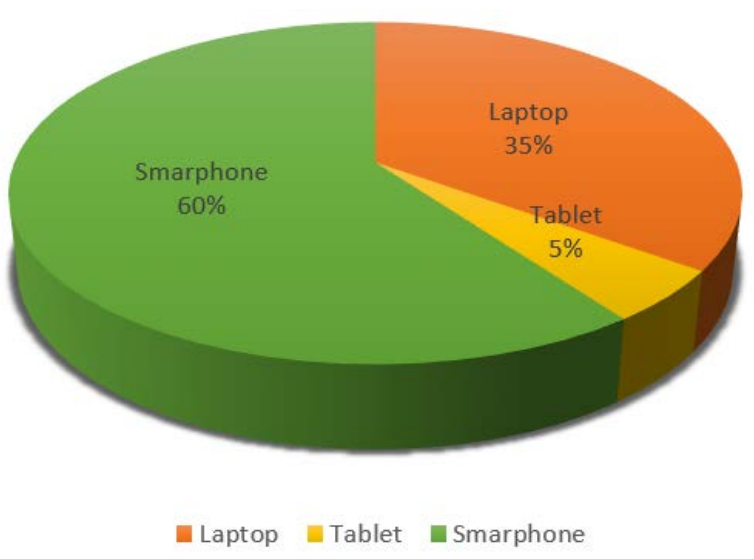

Figure 1. Types of mobile technology used

Figure 1 shows that $60 \%$ of students use smartphone in supporting their activities. The type of smartphone is chosen using Android. One of the reasons is of course because the smartphone is easy to carry with a small appearance. The second mobile technology device used is a laptop with 35\%. Laptops are the choices as a device that can help students learn. Next is the tablet; this device is less attractive to students; the percentage of usage is only $5 \%$.

\subsection{Access to the Internet Network Used}

Access the network used by students online and offline, as shown in the following figure:

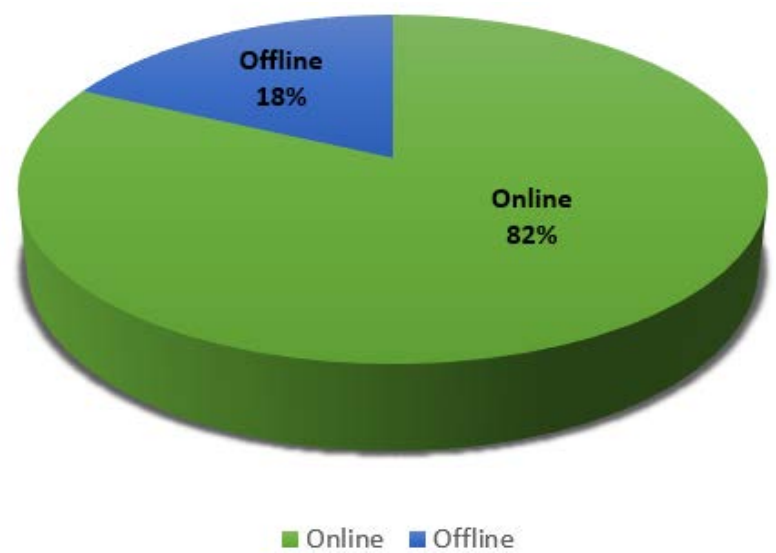

Figure 2. Access to the internet network used 
Figure 2 shows that the level of online use is $82 \%$, which means that almost all students can access network online. But there are still students who access the Internet offline for $18 \%$. It's happening because not all areas or places of residence of students can access the Internet online. Demographically student residences are scattered in rural areas that only rely on cellular providers in accessing the internet.

\subsection{Time Used in Using Mobile Technology}

This section describes the average time of use in using mobile technology devices, especially mobile devices per day. The answer consists of 3 parts, which are less than 1 to 2 hours with a low category, around 3-4 hours in the small grade and more than 5 hours with a high degree. As shown in the following figure:

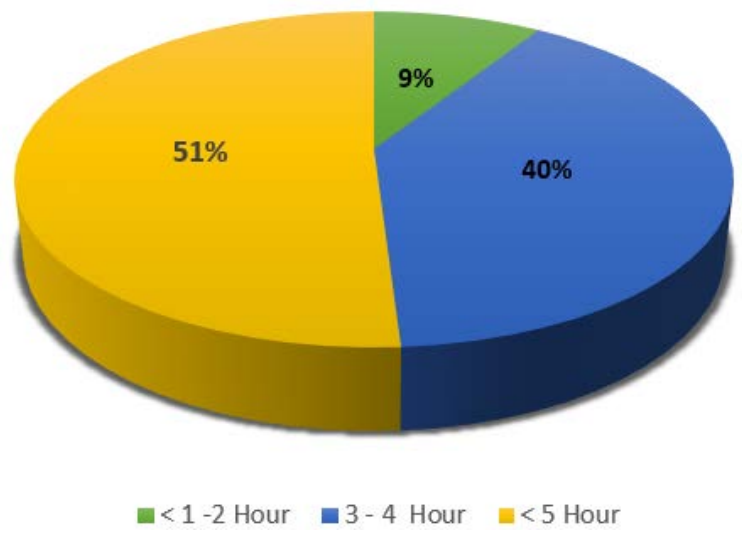

Figure 3. Access to the internet network used

Figure 3 shows that the time spent by students with mobile technology devices especially mobile devices varies. Students who use mobile technology in a low category are less than 1 to 2 hours per day at $9 \%$, and an average grade is $40 \%$ with a usage time of around 3 to 4 hours. However, more than half of students use mobile technology more than 5 hours per day which is $51 \%$. This data shows the level of students' interaction with mobile technology, unusually high cellular devices. Mobile learning has a great opportunity to be applied in education.

\subsection{Types of Mobile Applications That Are Often Used}

This section shows the types of mobile applications used by students as a means of supporting their activities. As shown in the following figure.

Generally the use of mobile technology applications can be categorized as a means of social media, means of communication, looking for news and information, games and infotainment, the rest will be used for other purposes. From the results of the questionnaire that has been distributed, as many as $40 \%$ of students use the mobile application as a communication tool. It is especially true of daily activities in interacting with family, friends and also others. $27 \%$ of them use the mobile application as social media and they claims that they use in this section such as Whatsapp, Facebook, Tweeter, Instagram, and so on. 16\% of students use the mobile application as a means to search for news and information on Google, Wikipedia, etc. As many as $15 \%$ use the mobile application for games and infotainment. Some of the games and entertainment applications are Youtube, Smule, Tiktok, $\mathrm{CoC}$ and other game applications. About $2 \%$ use the mobile application for others such as E-Commerce and so on.

From the results of this diagram, it can be a reference to how the design of the development of mobile learning models can do, for example, by combining learning into social media or vice versa. Design learning materials by utilizing infotainment applications makes it easier for students to access learning links videos, and many more designs that can do that are connected with the level of use of mobile apps. The design is expected to be able to assist students in learning and reach the standard of learning potential.

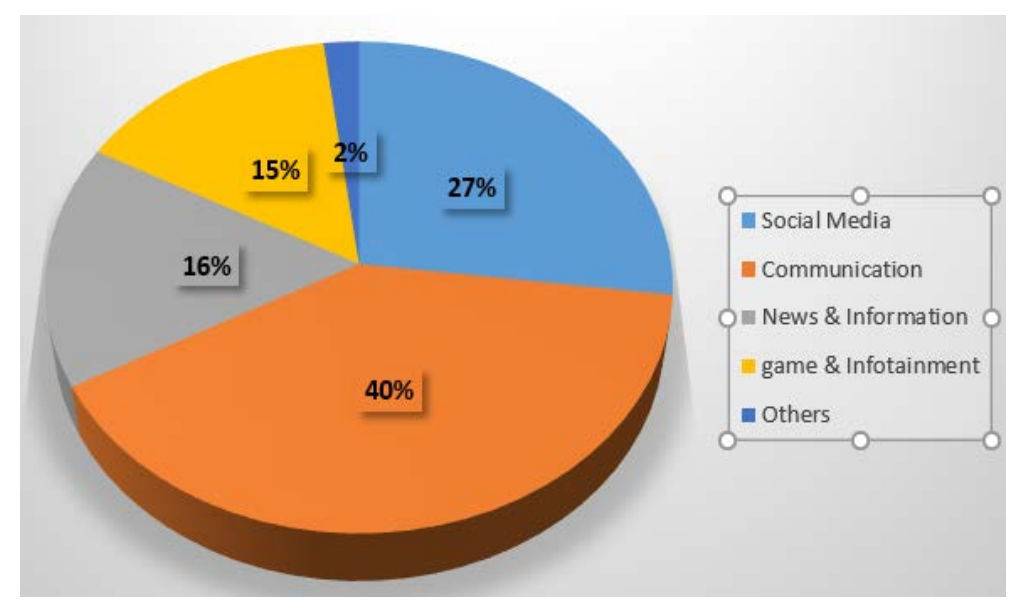

Figure 4. Type of mobile apps that used 


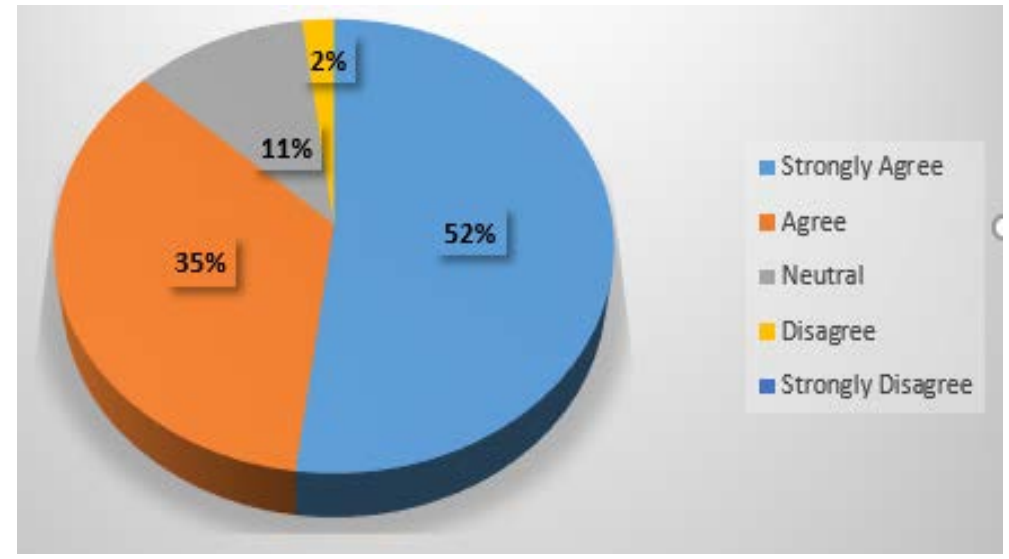

Figure 5. Student perceptions of mobile learning

\subsection{Students' Perceptions of Mobile Learning}

In this section, it measures students' perceptions of mobile learning. This becomes a reference in the design of the development of subsequent mobile learning. These results are shown in Figure 5.

Figure 5 shows that there are $2 \%$ of the students choosing to disagree and $11 \%$ neutral. About $35 \%$ of the students agree with the application of mobile learning. 52\% of students strongly agree on the implementation of mobile learning. It is in line with some characteristics of mobile learning that can facilitate students in education, Mobile learning can be used by students wherever and whenever. Mobile learning adds variety in learning. With mobile learning, students can communicate directly with the lecturer on discussion topics that have been provided in the learning platform and so on.

\section{Conclusions}

The level of student needs for mobile technology, unusually high cellular devices with an average usage time of more than 5 hours per day. The mobile application used is diverse but has not been used maximally for learning. That can be one of the foundations in the design and development of the mobile broadband model at universities. It is supported by the results of research that has conducted that $35 \%$ of students agree and $52 \%$ strongly agree on the adoption of a mobile learning model. The design of the mobile learning models must be adapted to the dominant mobile application used by students so that the utilization of the mobile learning model can be maximally utilized in learning. The mobile learning model is expected to be able to make education more attractive and accessible wherever and whenever.

\section{Acknowledgements}

This research work is supported by the Ministry of
Research, Technology, \& Higher Education, Indonesia (Doctoral Dissertation Research scheme of Universitas Negeri Jakarta).

\section{REFERENCES}

[1] Abu-Al-Aish, A., \& Love, S. (2013). Factors influencing students' acceptance of m-learning: An investigation in higher education. International Review of Research in Open and Distance Learning, 14(5), 82-107.

[2] Chong, JL, Chong, AYL, Ooi, KB, \& Lin, B. (2011). An empirical analysis of the adoption of m-learning in Malaysia. International Journal of Mobile Communications, 9(1), 1. https://doi.org/10.1504/ijmc.2011.037952

[3] Corbeil, JR, \& Valdes-corbeil, ME (2007). Mobile Learning? Are You Ready for. Word Journal of The International Linguistic Association, (2), 51-58.

[4] Göksu, İ., \& Atici, B. (2013). Need for Mobile Learning: Technologies and Opportunities. Procedia - Social and Behavioral Sciences, 103, 685-694. https://doi.org/10.1016/j.sbspro.2013.10.388

[5] Hamdani, DS Al. (2013). Mobile Learning: A Good Practice. Procedia - Social and Behavioral Sciences, 103, 665-674. https://doi.org/10.1016/j.sbspro.2013.10.386

[6] Hanif, M., Asrowi, A., \& Sunardi, S. (2018). Students' Accessibility and Perception on Using Mobile Technologies in Classroom: A Potential and Challenge to Mobile Learning Implementation. Journal of Education and Learning (EduLearn), 12(4), 644-650. https://doi.org/10.11591/EDULEARN.V12I4.8398

[7] Hwang, GJ, \& Chang, HF (2011). A formative assessment-based mobile learning approach to improving learning attitudes and achievements of students. Computers and Education, 56(4), 1023-1031. https://doi.org/10.1016/j.compedu.2010.12.002

[8] Ken Nee Chee, Noraffandy Yahaya, Nor Hasniza Ibrahim, \& Mohamed Noor Hasan. (2017). Review of \{Mobile\} \{Learning\} \{Trends\} 2010-2015: Journal of Educational Technology \& Society, 20(2), 113-126. Retrieved from 
http://www.jstor.org/stable/90002168

[9] Kim-soon, N., Tun, U., Onn, H., Gaani, M., Tun, U., Onn, H., ... Rahman, A. (2015). Innovation Management and Sustainable Economic Competitive Advantage: Khalid S. Soliman International Business Information Management Association (IBIMA). (November).

[10] Marinakou, E., \& Giousmpasoglou, C. (2015). Assessing the Role of Mobile Technologies and Distance Learning in Higher Education. Assessing the Role of Mobile Technologies and Distance Learning in Higher Education, $i$, 176-199. https://doi.org/10.1080/00207543.2015.1122249

[11] Naismith, L., Sharples, M., Vavoula, G., \& Lonsdale, P. (2004). A review of the literature and videos of tecnologias e aprendizagem. Retrieved from http://telearn.archives-ouvertes.fr/docs/00/19/01/43/PDF/N aismith_2004.pdf

[12] Rachmadhani, DP (2016). Descriptive Study of Student Perception on Guidance Teachers and Counseling in the Implementation of Individual Counseling Services. PSIKOPEDAGOGIA Journal of Guidance and Counseling, 5 (1), 57. https://doi.org/10.12928/psikopedagogia.v5i1.44 88

[13] Sönmez, A., Göçmez, L., Uygun, D., \& Ataizi, M. (2018) A review of Current Studies of Mobile Learning. Journal of Educational Technology and Online Learning, 1(1), 12-27. https://doi.org/10.31681/jetol.378241

[14] Your, U., Style, L., Carter, ML, Cooper, T., Anderson, R., Seyal, AH, ... Cernerud, L. (2014). Defining Mobile Learning in the Higher Education Landscape Research method. 13(3), 12-21. https://doi.org/10.5430/wje.v5n3p61 